\section{$3 \mathrm{SC} 51$}

\section{へム蛋白質の反応機構}

\author{
○渡辺芳人 (名大 ·院理 ·物質理学)
}

へム蛋白質・酵素は活性中心にへム（鉄ポルフイリン錯体）を共有 しながら、生体内で様っな機能を担っている。合成反応の触媒とい う観点からへム䤃素を眺めると、アルキル基や芳香環を水酸化する P450が重要な醉素と考えられる．例えば、緑膿菌由来の P450cam は 毎分 1,000 回程度の速度で $d$-camphor 5-exo-hydroxy camphorに変 換する。一方、ペルオキシダーゼは過酸化水素を酸化削として用いて おり、活性種である compound I の生成速度は $10^{7} \mathrm{M}^{-1} \mathrm{sec}^{-1}$ と非常 に速い。従って、ペルオキシダーゼを用いて水酸化反応を行えば、有 機合成上有用な生体触媒となりそうであるが、話はそれほど簡単では ない。それぞれのへム醉素はそれぞれの決まった反応のみを触媒する ために、ペルオキシダーゼによる覀酸化反応はほとんど進行しない。 合成錯体モデル研究の結果からは、ペルオキシダーゼの compound I でも酸化されるべき基質がへム鉄に近づくことができれば、水酸化反 応は可能であると考えられる。有機化学的手法で合成モデルを組み立 てたように、人為的に活性中心を蛋白質内部に作り上げることで、へ 么䣼素を生み出すことは可能であろうか？こうした問題意識の下、 酸素分子を筋肉中に貯蔵する役割を担っているミオグロビンのへム近 傍構造を反応論の見地から適切に改変することで、過酸化水素を利 用する酸化醅素に変換する試みを行った。野生型のミオグロビンは酸 化活性が低く、しかも不斉選択性もほとんど見られないのに対して、 ミュータントは高活性・高不斉選択性を示している。トリプトファン をミオグロビンのへム近傍に導入したミュータントでは、過酸化水素 を酸化郕として用いることで、ほほ化学量論的に位置選択的芳香環の 水酸化を達成するなど、人工的なへム酵素の設計に成功している。

Y.Watanabe : Molecular mechanisms of heme enzymes

\section{$3 \mathrm{SC} 53$}

\section{脱窒生物の一酸化窒素還元酵素の触媒反応機構}

○城 宜呞、汲田 英之、日野智也 (理化学研究所 播磨研究所)

脱窒は、脱窒菌や脱窒カビが硝酸イオンや亜硝酸イオンの還元に共役 して生体エネルギーを得る過程である。この脱窒過程においては、強 い細胞毒性を示す一酸化窒素（NO）が中間体として生成するので、 脱空生物は固有の一酸化空素還元醅素（NOR）を有し、NO を亜酸 化窒素 $\left(\mathrm{N}_{2} \mathrm{O}\right)$ に変換することにより無毒化している。この触媒反応 $\left(2 \mathrm{NO}+2 \mathrm{H}^{+}+2 \mathrm{e}^{-} \rightarrow \mathrm{N}_{2} \mathrm{O}+\mathrm{H}_{2} \mathrm{O}\right)$ には、N-O 結合の開裂と N-N 結合の生成という化学的に興味深いステップが含まれるている。脱空 カビNORは水溶性のへムタンパク質であり、チトクロムP450 と類似 構造を持つ。タンパク質 1 分子中に 1 分子含まれるへム鉄が活性中心 となっている。一方、脱窒菌 NORは膜結合性タンパク質であり、分子 進化的に哺乳動物のチトクロム酸化醳素と同じ祖先を有すると考えら れている。1 分子中に 3 つのへム鉄と 1 つの非へム鉄を有し、その中 で1つの高スピンへムと非へム鉄が触媒部位を形成している。このよ うな活性中心の構造の違いから、触媒反応機構が雨酵素で異なると考 えれる事から、我タはこれらの分子機構を詳細に検討した。脱窒カビ NORでは、鉄に結合したNO $\left(\mathrm{Fe}^{3+}-\mathrm{NO}\right)$ を 2 電子/プロトンで活性 化することにより反応が進み (Activation Mechanism)、脱窒菌 NOR では、鉄に結合した 2 分子の $\mathrm{NO}\left(\mathrm{Fe}^{2+}-\mathrm{NO}-\mathrm{ON}-\mathrm{Fe}^{2+}\right)$ が近くに存 在することにより $\mathrm{N}-\mathrm{N}$ 結合を形成する機構（Proximity Mechanism） を提案した。

$\overline{\text { Y. Shiro, H. Kumita, T. Hino : Molecular mechanism of NO reduction }}$ by nitric oxide reductases

\section{$3 \mathrm{SC} 52$}

ヘムオキシゲナーゼの反応中間体の構造解析

○海野昌喜、松井 敏高、齋藤 正男（東北大·多元研）

へムオキシゲナーゼ（HO）はへムを酸化的に分解する酵素であり、 へム代謝や細胞内シグナリング・生体防御などに重要な役割を担って いる。また病原性細菌は、生存に必須な鉄をこの醅素を使って獾得し ている。HOによるへム分解は、酸化型へムを、還元型、酸素化型、 パーオキシ型、ヒドロキシ型、ベルドへム型という多段階を踏んで、 ビルベルジンへと変換する反応である。この反応では、基質であるへ ム自らが酸素を活性化することやへムの $\alpha$ 一ソ位のみが開裂される ことなど、そのメカニズムには興味深い点が多い。また、パーオキシ 型活性種を用い効率的にへムを水酸化している点はHO独特であり、 酸素活性化機構およびそれを可能にする特殊な構造因子について注 目されている。我々はジフテリア菌由来の HOである HmuOの酸 化型・還元型・酸素化型およびビリベルジン型の構造を高分解能で明 らかにした。特に酸素化型は不安定な中間体であるため、その結晶は グローブボックスを用いた高度な笑験技術で作製され、結晶用分光器 を用いX 線回折実験前後で酸素化型であることを確認し、慎重に構 造解析された。得られた構造からは、タンパク部分の立体効果により 酸素分子の配向が簃密に規定され、約 110 度の Fe-O-O 結合角でへム の $\alpha$ ーメソ位方向に向いていること、またタンパク質内に取り込まれ た水分子が水秦結合によって酸素化型を安定化していることなどが明 らかになった。さらに我々は、「極低温 $\gamma$ 線照射還元法」を応用した パーオキシ型の結晶構造解析に着手している。本会議では分光学的 手法や X 線結晶学的手法により得られた知見により、酸素化型およ びパーオキシ型 $\mathrm{HmuO}$ の構造を中心に、HO 反応中間体の構造につ いて議論する。

M. Unno, T. Matsui, M. Ikeda-Saito : Structural Analysis of Reaction Intermediates of Heme Oxygenase Catalysis

\section{SC54}

キサンチン脱水素酵素におけるモリブデン水酸化反 応中間体の構造と反応機構

○岡本 研 ${ }^{1}$ 、松本 浩二 1,2 、山口雄一郎 ${ }^{3}$ 、松村智裕 ${ }^{1}$ 、 Hille Russ $^{4}$ 、Eger Bryan ${ }^{5} 、$ Pai Emil ${ }^{5}$ 、西野 武士 ${ }^{1}{ }^{1}$ 日医大・生 化、 ${ }^{2}$ 富士薬品、 3 慈恵医大·腎臓高血圧内科、 ${ }^{4}$ オ八イオ州 立大·分子細胞生物、5トロント大・医)

キサンチン酸化還元醉素 $(\mathrm{XOR})$ は細菌からヒトまで多くの生物種に 存在し、補酳素として、サブユニットあたり 1個の FAD、2 個の Fe2S2 型の鉄硫黄中心、1 個のモリブドプテリンを持つ。XORは広い基質 特異性を持っており、アルデヒド、プリン、プテリン、プテリジンな どの多くの化合物を水酸化する。その際基質を酸化し水分子の酸素を 水酸基として導入する。この反応はXORに特有のものであり、モリ ブドプテリンにおいて行なわれる。EXAFSによればモリブデンは 2 個の硫黄原子を介してプテリンと結合しており、それに加えて、=0、 =S、-OH が配位している。-OH は溶液中で水と交換されるため、生 成物の水酸基へと導入されるのはこの酸素原子であると考えられてい る。XORはヒトにおいてはプリン分解系の最終段階、ヒポキサンチ ンからキサンチン、キサンチンから尿酸への反応を触媒する。このた め、XORの阻害剤は痛風の治療薬として広く用いられている。今回 使用した化合物 FYX-051は本来 XOR 活性を阻害し、痛風治療薬と して使用する目的で開発されたものである。我々の解析の結果、この 化合物は反応の遅い基質であり、モリブデンと安定な反応中間体を形 成することが確認された。我々はFYX-051 と牛乳から精製したXOR の複合体の結晶を作成し、1.9 A の分解能で結晶構造を決定した。結 晶構造ではモリブデンと FYX-051 間に共有結合が存在していること が確認された。また、我々はヒトXORモリブデン周囲の基質認識残 基を変異させた醉素を作製し、醉素学的解析を行なった。この結果、 プリンを基質とした場合 E1261、E802、R880 が水酸化反応、基質認 識に必須であることがわかった。構造情報に加え、分光学的醅素学的 解析結果を総合して XORの反応機構の詳細を議論する。

K.Okamoto, K.Matsumoto, Y.Yamaguchi, T.Matsumura, R.Hille B.T.Eger, E.F.Pai and T.Nishino: Intermediate structure and hydroxylation mechanism of xanthine oxidoreductase 